\title{
Small Business and Social Enterprise: To Thrive Not Fail
}

\author{
Tina M. Barton
}

Small businesses (those with up to 99 employees) are the most common business type in Canada - comprising 97.9 per cent of businesses, and contributing close to one-third of Canada's gross domestic product (GDP). Yet a significant number of these businesses fail, with only about 50 per cent lasting at least five years, according to Industry Canada. Social enterprises - businesses that provide valuable products or services while delivering social and sometime environmental returns - struggle even more than small businesses to attract finance, grow, and sustain. What are the similarities and differences between these two groups' needs, and how can Canada's three levels of government and the broader business ecosystem better support small businesses and social enterprises to thrive? This paper takes a comprehensive look at key business needs, barriers to success, enabling factors, and policy incentives, drawing upon academic literature, studies and reports from the government, non-profit, and social enterprise sectors, as well as recommendations from business advocacy groups primarily from Canada and the United States.

Keywords: Small business, social enterprise, business financing, business growth, business ecosystem, procurement policy

\section{Introduction}

Small businesses are a critical contributor to Canada's economy and gross domestic product (GDP). Many businesses enter and exit the marketplace each year. Some thrive, grow, and sustain themselves, however many fail, especially between years two and five (Industry Canada, 2012). Social enterprises - a newer business model that focuses on social and sometimes environmental objectives - follow a similar pattern, although marketplace entry and exit data does not exist in Canada specific to social enterprises. This paper examines the conditions that

increase the likelihood of sustained success for small businesses and social enterprises while also exploring the distinct needs, challenges, and protective factors surrounding both. At the outset, this paper explains what qualifies as a 'small business' in Canada, before exploring how critical startup decisions such as choice of business model affects everything from profit share to liability. Barriers to success, and key knowledge and supports - both internal and external to a business - are examined, along with the types of financing sources most commonly accessed by and useful to small businesses. (In this paper, success is regarded as but not limited to delivering financial returns (and social returns in the case of social enterprises), operating without a deficit, growing staff size and revenue over time, and expanding market share). The second half of the paper repeats this format for social enterprises outlining the three most common business 
structures and implications for financing then moving to the unique value of social enterprises, obstacles, and opportunities. The paper concludes by highlighting favourable conditions that can help small businesses and social enterprises to achieve and sustain success.

\section{Methodology}

This paper includes a wide review of economic development literature from for-profit, non-profit and social enterprise communities as well as sector statistics provided by departments within the Government of Canada, academic literature, business associations' resources, survey data, and thought leadership articles. The sources are primarily from Canada and the United States, with a brief look at the social enterprise experience in Scotland. In examining the needs and experience of the small business and social enterprise sectors, it becomes apparent that support that works well for one sector is not always available to the other or guaranteed to have the same impact. A challenge is that data around the performance of social enterprises in Canada is limited - the Government of Canada does not track annual revenue for this group, nor entry and exit rates specific to this sector.

Future reports could expand upon the findings of this paper by looking at the emerging field of Indigenous-led social enterprise. Given the relative newness of that sector, plus complexities surrounding the subject (such as multi-generational trauma from the residential school system and other colonial biases still being experienced to this day), this paper does not cover the topic of Indigenous social enterprise beyond acknowledging here that minority and racialized entrepreneurs can face more barriers to starting and growing their businesses.

In terms of scope, small businesses in Canada are classified as those with up to 99 employees. A medium-sized business has 100 to 499 paid employees, and a large business has 500 or more paid employees (Innovation, Science and Economic Development Canada, 2016).

\section{Contributions of Small Business in Canada}

Small businesses play a vital role in Canada. First, on account of sheer volume; small businesses vastly outnumber medium- and large-sized businesses. As of December 2015, 97.9 per cent of businesses in Canada were small businesses $(1,143,630)$, compared to 1.8 per cent for mediumsized businesses $(21,415)$, and 0.3 per cent for large businesses $(2,933)$ (Innovation, Science and Economic Development Canada, 2016). When looking at the contribution to GDP from small businesses with less than 50 employees, Innovation, Science and Economic Development Canada found this group contributed close to one third of Canada's GDP.

When taking a closer look at Canada's small businesses, it soon becomes apparent just how small they are. Just over half (54.1 per cent) of small businesses are actually 'micro-enterprises', consisting of just one to four employees (Innovation, Science and Economic Development Canada, 2016). 
Small businesses also have a significant impact on Canada's economy by virtue of being the largest private sector employer in Canada, employing 70.5 percent of the total private sector workforce - 8.2 million people. By comparison, medium-sized businesses employ 2.3 million people (19.8 percent) and large businesses just 1.1 million people (9.7 percent) (Innovation, Science and Economic Development Canada, 2016).

A study released by the Global Entrepreneurship Monitor in May 2015 found that Canada had the second highest levels of entrepreneurial activity among 'Group of Seven' countries, after the United States (Grant, 2015). However, Industry Canada has estimated that while about 85 per cent of businesses that enter the marketplace survive one full year, 70 per cent survive for two years, and just 51 per cent reach five years (Industry Canada, 2012). There remains strong growth potential for small businesses, however. According to a study from the Business Development Bank of Canada, released in 2016, between 2001 and 2013 small businesses grew 20.5 per cent and micro-enterprises 21.8 per cent, compared to just 8.5 per cent for mediumsized businesses, and 11.6 per cent for large businesses (Ratté, 2016). This highlights the economic potential of micro-enterprises and small businesses, while reinforcing the importance of creating economic conditions that will assist them in growing and sustaining.

If Canada's small businesses cannot thrive, fewer medium-sized businesses will materialize.

\section{Starting and Growing a Business}

There are several common motivators behind creating a business; typically, people are inspired by a passion - they wish to provide a specific product or service to meet a need. Otherwise they may view running their own business as the best way to make money. For example, a study from America's nationwide network of Small Business Development Centers found that Millennials (those born between 1980 and 2000) are more likely to have started a business than Baby Boomers (those born between 1946 and 1965), and that Millennials are doing so because they trust themselves to provide their own financial security more than they trust others (Abrams, 2017). However, a limitation with starting a business based on a passion is that the necessary business skills may not be in place. A study published in Harvard Business Review validates this position, finding that most serial entrepreneurs displayed common traits of great leadership, persuasion, accountability, and goal-orientation, yet significantly lacked planning, organizing, time management skills, and empathy (Bonnstetter, 2013). A study by CB Insights, a United States-based market intelligence company, found that the main reasons startups fail include: no market need, poor product, lack of cashflow, lack of business model, poor marketing, and having the wrong team in place (Henry, 2017). Both of these studies serve to highlight just how important it is for business owners to possess strong business planning, marketing, investment readiness and deal-making skills - themselves or on their team - in order to succeed. The Canadian Federation of Independent Business (CFIB) provides a framework for entrepreneurs 
wishing to start a business, which includes choosing the most suitable business structure as a starting point. Options include sole proprietorship, incorporation and partnership (Canadian Federation of Independent Business, n.d.). New entrepreneurs commonly use sole proprietorship because it is the simplest model and easy to start. However, there is no distinction between the owner and business, which means that all business debts and liabilities rest with the owner, making it financially risky for the individual. The second model is incorporation where shareholders own the business. Business incorporation is more complicated and expensive to administer; however, the business is separated from the owner, which limits personal liability. There are also tax advantages for Canadian businesses, including Lifetime Capital Gains Exemption, and Small Business Corporate Tax Rate. The third model - partnerships - divides income according to the partnership agreement, and sees partners jointly accountable for debts and liabilities (Canadian Federation of Independent Business, n.d.). This partnership structure is most commonly chosen when multiple parties seek ownership. Particularly in this instance, it is important to have an exit plan in place from the outset that defines how partners can leave a business to prevent any legal disputes.

\section{Conditions for Growing Small Businesses}

\section{Access to Finance: Private Capital and Government Grants}

Access to finance is a key barrier for startups. A progress report on 'Goldman Sachs 10,000 small businesses', developed by Babson College, found that the self-reported top business challenges were: finding and keeping customers (31 per cent), financing the business ( 21 per cent), developing and maintaining a business strategy (16 per cent), and hiring and keeping good employees at reasonable wages (15 per cent) (Greene, 2014). In contrast, a report from Johns Hopkins University that looked at economic growth in Baltimore City found the greatest need was for more financing options (Miller, Seigel, \& McComas, 2017).

Typically, owners lack a credit history, and the assets or collateral needed to secure a business loan. In Canada, over 80 per cent of entrepreneurs have had to use personal financing to start their new business (Innovation, Science and Economic Development Canada, 2016). Not only is this risky for the owner, but it also shows the challenge to small businesses of accessing financing and highlights the limited range of financing options available. When it comes to attracting investment, the challenge for new businesses is that investors typically desire a good track record and indication of business success likelihood, which places startups in a catch-22 scenario because they require startup financing in order to build that track record. Statistics Canada tracks the types of financing requested by small businesses. In its 2014 Survey on Financing and Growth of Small and Medium Enterprises, Statistics Canada found the most commonly requested financing was trade credit (where suppliers let a business buy now and pay later) at 29.4 per cent, followed by debt financing (where creditors receive repayment of 
principal plus interest) at 28.1 per cent, capital leasing (renting an asset) at 7.9 per cent, and government grants at 4.4 per cent (Statistics Canada, 2014 cited in Innovation, Science and Economic Development Canada, 2016, p. 13). In looking at the primary sources of financing instruments accessed by small- and medium-sized startups, the same report found that personal financing was predominantly used at 84.3 per cent, with credit from financial institutions next at 44.9 per cent. A challenge is that most banks do not provide large three- to five-year loans, which excludes banks as financing sources (Menon, Swarup, Nicholson, and Khan, 2015). In addition, small businesses often do not meet the profitability requirements to qualify for commercial funds. Given the reliance on financial institutions, these statistics suggest that the biggest impact for improving the availability of financing to small businesses would be to relax the lending policies of banks and credit unions, as opposed to focusing on government policies. This is covered more thoroughly in the 'Creating supportive conditions for small businesses' section of this paper.

Briefly, the most popular government grants for small businesses in Canada can be categorized into four areas: Business expansion funding grants and loans, capital investment funding, hiring and training grants, and research and development funding (MentorWorks, n.d.a). Community Futures Development Corporations (CFDCs) offer businesses another important source of loans, planning services and business coaching (Ries, 2016). Another advantage is that CFDCs provide multi-year core funding (in addition to project-based funding), an essential and often missing component, as discussed elsewhere in this paper. CFDCs invest in both types of enterprise, forprofits and non-profits (McKinnon, n.d.). A survey of 512 CFDC clients, 79 CFDC representatives, 73 community partners involved in program delivery, and 12 representatives of FedDev Ontario, along with analysis of project data from 2009-10 to 2011-12, and 2012-13 where feasible, found that CFDC loan clients grew faster, had higher rates of survival, and generated an estimated additional $\$ 516$ million in revenues, 3,865 jobs, and almost \$130 million in wages over a five year period compared to similar businesses that did not receive loans (Ference Weicker \& Company Ltd., 2014, (page number not available)). The study also found that CFDC-supported businesses had higher survival rates ( 88 per cent compared to 66 per cent) after five years.years.

\section{The Business Incubator Effect}

Business incubators are intended to accelerate the growth and success of startups/small businesses. Experts provide day-to-day support to help tenant companies survive and grow during the period when they are most vulnerable to failure (Almubartaki, Al-Karaghouli, \& Busler, 2010). Business support services include: concept ideation, business planning, financial coaching and access to finance, market and competitor analysis, marketing strategy, and talent support through to product launch and access to new markets (Almubartaki et al, 2010). In addition, the incubator programs can offer entrepreneurial firms shared office services, plus 
access to more equipment and meeting room space. Different types of incubators include: mixeduse (clients from multiple sectors), technology incubators, manufacturing incubators, and microenterprise incubators (Almubartaki et al, 2010).

Business incubators have been shown to accelerate business growth, make financing more accessible, and reduce the rate of failure among new enterprises. While scholars acknowledge the lack of research in the field around impact and sustainability (Cohen \& Hochberg, 2014; Dempwolf et al., 2014; Fehder \& Hochberg, 2014 cited in Tasic, Montoro-Sánchez, \& Cano, n.d.), statistics that do exist suggest between 70 per cent (Ogutu \& Kihonge, 2013) to 90 per cent of businesses that graduated out of incubator programs are still in business, compared to approximately 30 per cent of non-incubated businesses (NBIA, 2000 cited in Almubartaki et al, 2010; Wilber \& Dixon, n.d.). The NBIA study, which analyzed 50 business incubators and 126 of their affiliated firms that entered the incubators between 1990 and 1996, with a comparative analysis of businesses not in incubators between 1989 and 1992, found that only 39.5 per cent of non-incubator businesses had a life span of even six years, compared to the 87 per cent of incubated businesses that lasted nine years (Wilber \& Dixon, n.d.). This suggests that incubators significantly increase survival rates and longevity of startups. Reasons for this include the constant presence and support of business strategists and experts, the cost sharing, the expanded networks for more business opportunities, and the reduced risk that comes with all of these supportive factors. Another study, focused on accelerators (the next level of mentorship and counsel) found that among four cohorts of 45 accepted ventures in the U.S., the likelihood of being alive or acquired increased by a range of 20.8 to 34.5 per cent (Hallen, Bingham, \& Cohen, 2014). There are more than 150 business incubators in Canada (some offering physical incubation space, others providing resources and support without office space). Canada's betterknown incubators include: Accelerator Centre (Waterloo), Anges Québec, Artscape (Toronto), BC Innovation Council, BrightSpark Ventures (Toronto), Canadian Innovation Centre (Waterloo), Invest Ottawa, Innovacorp (Nova Scotia), Innovate Manitoba, Innovate Niagara, Innovation PEI, MaRS (Ontario), Launch Academy (Vancouver), McMaster Innovation Park (Hamilton), Northern Alberta Business Incubator, Northwestern Ontario Innovation Centre, Okanagan Research and Innovation Center, Startup Canada, Startup Edmonton, Velocity (University of Waterloo), and UTEST (University of Toronto) (Kalender, 2017).

Getting accepted into a business incubator can be competitive and challenging. Each incubator offers a different entry process, most beginning with an online application where certain criteria must be met before candidates may proceed to the interview stage. There can also be restrictions on eligibility; for example, Invest Ottawa indicates a preference for accepting for-profit companies at the early stage of developing technology, SaaS, apps, IP or an innovative productbased business. According to its website; service providers, academic groups, non-profits, social enterprises, and importers are not eligible to participate (Invest Ottawa, n.d.). In contrast, the Northern Alberta Business Incubator and Vancouver's Launch Academy do not indicate such 
restrictions on eligibility, according to their websites (Northern Alberta Business Incubator, 2014; Launch Academy, n.d.). To increase the likelihood of attracting investment, startups can follow these tips: know everything about the incubator or investor (interests, other clients, services they will provide beyond investment), get a warm introduction if possible, perfect your pitch before the first interview, and ideally be prepared to cover your business model, technical details, and implementation plans (Goldstein, n.d.).

\section{Franchising}

Franchising is another option to help businesses scale. That is, instead of starting a new business, an entrepreneur or rather a 'franchisee' could purchase the rights to an existing brand and the operations model from a franchisor (Hurley, 2016). The benefits to the franchisee include inheriting an established business model, operational support, and an evidence base for success, which can make it easier to attract financing. Many franchising contracts also include the provision of training, marketing, and product supply to the franchisee (Hurley, 2016). In return, the franchiser receives royalties, which may also be amplified by the franchisee's local community knowledge and networks, which could translate into more sales. Franchising comes with its own set of regulations and contracts to navigate, which some entrepreneurs may shy away from. Further, entrepreneurs that wish to set their own path and not answer to anyone else may choose to not take the franchising route.

\section{Succession Planning}

A succession plan is vital to keep a business going, yet this is an often-neglected key area. In 2012, the Canadian Federation of Independent Business reported that even informal succession plans only existed in 40 per cent of Canadian small businesses (Canadian Federation of Independent Business, 2012, cited in Weaver, 2014). Succession planning is complex and may take several years. Critical steps include ensuring the business plan and vision is up to date, evaluating the worth of the business, considering whether a suitable successor is known to the existing owner, and preparing a training and exit strategy (Canada Business Network, n.d.).

\section{Creating a Supportive Environment for Small Businesses}

\section{Pairing Investors and Businesses}

Businesses largely depend on credit from financial institutions, second to personal financing, as noted above. This, in part, could be that in order to be eligible for Canadian government funding, businesses need to be incorporated for at least three years and have at least five people on 
payroll, although each funding program has its own eligibility requirements (MentorWorks n.d.b). This means expanding the private sector financing options available to small businesses should be a priority in Canada. The aforementioned Johns Hopkins University report outlines key recommendations for improving local financing that includes: better measurement and tracking of capital flows and businesses, more efforts to match businesses with investors, and enhancements to local lending capacity (Miller, Seigel, \& McComas, 2017). This creates an opportunity for economic development and business associations in a city to form alliances and pursue closer relationships with the municipal government to advance these improvements to capital flows and lending.

\section{Opening Up Procurement Opportunities and Supports}

A study in the United States conducted to measure small business job creation in five cities Chicago, Dallas, Detroit, Los Angeles, and Washington, D.C. - found that in four of those five cities small businesses create the most new jobs. In Los Angeles that rate was the highest at 74 per cent. Given the significant economic impact and job creation potential, the report recommended that cities invest more in creating a supportive ecosystem to nurture small business growth (Bowdler and Zeull, 2016). The authors recommended that municipal governments expand contracting opportunities to allow small businesses to be more competitive and therefore more easily able to be awarded government contracts, to ease burdensome regulations by making existing resources more accessible, and to design workforce programs to help small businesses recruit and train new employees.

\section{Advocating for Improved Federal Government Supports to Small Businesses}

Federal (and provincial) government policies also have a profound impact on the viability and longevity of small businesses (which makes the election cycle and potential change of political will an unpredictable variable). One example is the federal government's practice of only taxing 50 per cent of a business's capital gains (Department of Finance, Government of Canada, 2017). However, a recent decision causing controversy among the business community is the federal government's proposal to more thoroughly regulate income-splitting among family members. Business owners will now need to meet a 'reasonableness test' to prove to the Canada Revenue Agency that their family members have made a meaningful contribution to the business through labour or property, or by assuming risks (Canadian Federation of Independent Business, 2017a). The federal government also reneged on a promise to reduce the small business tax rate from 10.5 per cent to 9 per cent, but after pressure from small businesses and associations has recommitted to having this tax cut take effect by January 2019 (Canadian Federation of Independent Business, 2017b). 


\section{Exports: Tapping the Global Market for Success}

The export market represents a significant opportunity for businesses. Yet approximately just 10 per cent of Canadian small- and medium-sized businesses are involved in exports (Tal \& Mendes, 2015). In January 2016, the Canadian government announced \$50 million to help smalland medium-sized businesses (SME) explore global export markets. In order to be eligible for the program, companies are required to have annual revenue in Canada between $\$ 200,000$ and $\$ 50$ million (Galang, 2016). At the end of the first year of its SME export assistance program, the Government of Canada reported that 500 Canadian small- and medium-sized enterprises had been funded to reach new international markets, with matching contributions of between $\$ 10,000$ and \$100,000 (Global Affairs Canada, 2016). The government did not specify the percentage of small- versus medium-sized businesses receiving this funding, so it is not possible to compare participation rates based on company size.

Officials at Industry Canada believe it is possible to generate stronger, even 'superior', financial performance through export markets, as stated in their 2015 SME Profile on Canadian Exporters (Seens, 2015). With data coming from over 10,000 respondents to the 2011 Survey on Financing and Growth of Small and Medium Enterprises developed by Statistics Canada and Industry Canada, the survey found that export businesses among small and medium enterprises increased their sales by 20 per cent or more per year over the 2009-2011 period compared with eight per cent for non-exporters (Seens, 2015). Exporters also generated higher pre-tax profit margins and returns on assets. Exporting is a complex process given foreign business regulations, the presence or absence of free trade agreements, foreign market knowledge, access and competition, reliance on a foreign supply chain or delivery mechanisms, etc., however if done correctly, the above findings suggest that the returns can justify the efforts. For entrepreneurs contemplating the export market, Business Development Bank of Canada and Export Development Canada offer many resources. As a starting point, business owners must become informed about tax and business regulations in the foreign country, market demand and buying culture, competition in the market, labour availability, shipping costs, and insurance considerations (Business Development Bank of Canada, n.d.). Typically, it is the larger-sized businesses in the SME category that tend to export, as these businesses possess greater capacity and networks. Only seven per cent of micro businesses exported in 2011, compared with 11 per cent of businesses with five to 19 employees, and 19 per cent of businesses with 20 to 99 employees (Seens, 2015). The United States was the predominant export market, with 74 per

cent of small business exports focused there, compared to 10.7 per cent in Europe, 3.7 per cent in China, and 2.7 per cent in Latin America (Seens, 2015). On average, this data revealed that exports contributed an extra 35.3 per cent of revenue for small businesses, which shows the growth and profit potential of exporting. 


\section{Conditions for Success for Social Enterprise in Canada}

Social enterprises are businesses with social and sometimes environmental objectives that reinvest profits back into the business. This differs from a traditional business, which distributes its profits to owners and shareholders (Government of British Columbia, n.d.). As of 2015, there were more than 7,000 confirmed social enterprises across Canada (Elson, Hall, \& Wamucii, 2016), which is significantly less than the 1.14 million small businesses in Canada.

Reportedly, Canada is one of the best places in the world for social entrepreneurs, according to a survey by Thomson Reuters Foundation and Deutsche Bank. The survey; which was completed by more than 600 academics, social entrepreneurs, investors, policy makers and support network staff across 45 countries; gave Canada the highest ranking for ease of access to investment and for the ability for social entrepreneurs to make a living from the work (Ontario Investment Office, 2017). Further to this, a 2016 Canadian National Social Enterprise Sector Survey Report from Elson et al (2016) found that Canada's social enterprise sector can be profitable. Among the 1,350 social enterprises that responded to the survey (which did not include social enterprises in Québec), the net profits generated in a year were $\$ 58.5$ million, an average of $\$ 59,000$ per enterprise (Elson et al, 2016). This is interesting as the social enterprise sector is generally known to have small profitability margins on account of its focus on social returns - sometimes at the expense of financial returns. Social returns can include employing more vulnerable, disabled and less educated staff members whom may require more training and coaching, which incurs more costs and time.

The National Social Enterprise Sector Survey Report provides an insightful look into factors such as hiring rates, profitability, and recipient rates for government grants. The report examines distinct focus areas within the social enterprise sector, including cultural, disability-focused, income-focused, employment, training, urban and rural. Of note, income-focused social enterprises (defined as selling goods or services to create a blended financial, social, environmental or cultural return) reported earning on average five times the net profits compared to other social enterprise types, while training-purpose social enterprises reported earning on average almost three times the net profits of other social enterprises (Elson et al, 2016). Culturalpurpose social enterprises reported receiving less operating grants than the average social enterprise, and were less profitable. Environmental-purpose social enterprises reported receiving more grants and donations than other social enterprises, and engaged a total of 74,000 volunteers - more than four times the average. Poverty-focused social enterprises reported employing more people than others on average, yet fewer reported receiving operating grants from all three levels of government compared to other social enterprises (Elson et al, 2016). This could be related to the fact that poverty-focused social enterprises were almost twice as likely to be less than five years old, so missing the desired track record. When classified by age, 17 per cent of responding 
social enterprises were zero to five years old, 21 per cent were six to 15 years old, and 62 per cent were 16 years or more in age (Elson et al, 2016).

Figure 1: Age of Social Enterprises

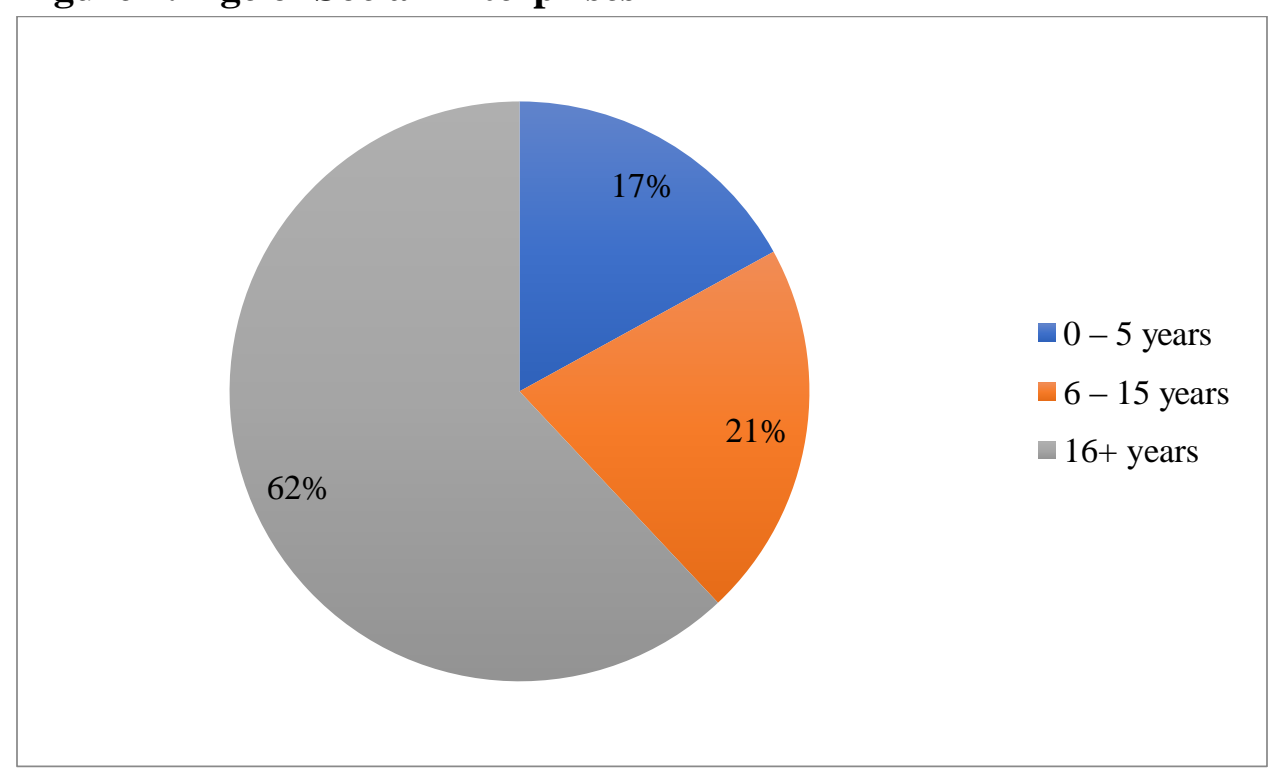

Figure 1. Age of Social Enterprises. Adapted from Canadian National Social Enterprise Sector Survey Report 2016 (Elson, Hall \& Wamucii, 2016).

There appears to be little available literature on the contribution of social enterprises to GDP. In 2002, the Canada Revenue Agency collected data on how charitable organizations generate revenue through market-driven activities (such as charging fees for services or receiving revenue from renting or selling assets). Using that data, a team at Enterprising Non-Profits calculated that this segment contributed over 2.8 per cent of Canada's GDP in 2002, offering a benchmark assessment of the contribution of social enterprises to GDP (Enterprising Non-Profits, 2010). Efforts should be made to update the collection of data to measure the financial performance of the social enterprise sector. Of course, the challenge there resides in the definition of a social enterprise - it is reasonable to assume that if a definition were to include cooperatives, credit unions, and non-profits, the GDP share would be much more sizeable than if the definition strictly focused on businesses that primarily identify as social enterprises.

\section{Models of Social Enterprise}

When starting out, social enterprises must consider which model to adopt: for-profit, non-profit (including whether or not to register as a charity) or co-op. Legal counsel is recommended due to the complexities of each model. Each contains pros and cons. For example, a for-profit social enterprise might attract more investors because investors typically seek the greatest financial returns possible, which cannot always be achieved by non-profits with other goals too, such as getting disabled or disadvantaged people into the workforce. However, for-profit social 
enterprises are restricted from accessing government funding and shareholders may insist any profits be paid to them rather than reinvested into the enterprise to advance social goals (Futurpreneur Canada, n.d.). Whereas, non-profit social enterprises may be tax exempt or receive taxation benefits and find it easier to attract grants and government support, owners and investors are restricted from paying dividends, which can again reduce investors' interest and restrict the owner's ability to raise capital (Futurpreneur Canada, n.d.). This increases non-profit enterprises' reliance on grants as opposed to private capital. Furthermore, the Canada Revenue Agency (CRA) limits the ability of non-profit social enterprises to accumulate revenue reserves to support growth, meaning they cannot save significant profits for future use and, as a consequence, non-profit social enterprises have less collateral to offer banks when securing operating loans (Broder 2010, cited in O'Connor, 2014). The advantages for a non-profit social enterprise to register as a charity include: the ability to issue tax receipts for donations - a considerable incentive for donors, eligibility for government grants (although there may be restrictions on the types of expenses that can be funded), and being exempt from income tax on earnings (MaRS, 2009). The disadvantages include limited access and likelihood of receiving investment capital, and inability to accumulate profits as aforementioned, in this case because the CRA requires a charity to spend 80 per cent of the value of its receipted donations from the previous year on charitable purposes (MaRS, 2009). Naturally, these restrictions limit the ability of a social enterprise to grow (or scale up).

The advantages of the co-operative model are that membership shares and investment shares can be issued to raise equity capital, the co-op can operate as either a for-profit or non-profit, and be eligible for a range of government programs. The disadvantages include that some government programs require a 51 per cent ownership, which co-ops typically do not support (Futurpreneur Canada, n.d.). Co-ops can also encounter challenges in sustaining engagement and participation among their members, and managing the governance.

\section{Assisting Social Entrepreneurs in Choosing Their Model}

The significant number of factors to consider when choosing a business model can be overwhelming. Social enterprise leaders would benefit from consulting business advisors and legal aid to assist them in choosing the most advantageous model for their needs. Using a decision tree process as displayed below (this one designed by Social Delta, a Canadian consultancy for social enterprise) would help to simplify the decision-making by guiding social enterprise leaders through key considerations, from governing intellectual property to issuing shares and sharing profits. 
Figure 2: Your Amazing Social Enterprise Idea [Decision Tree]

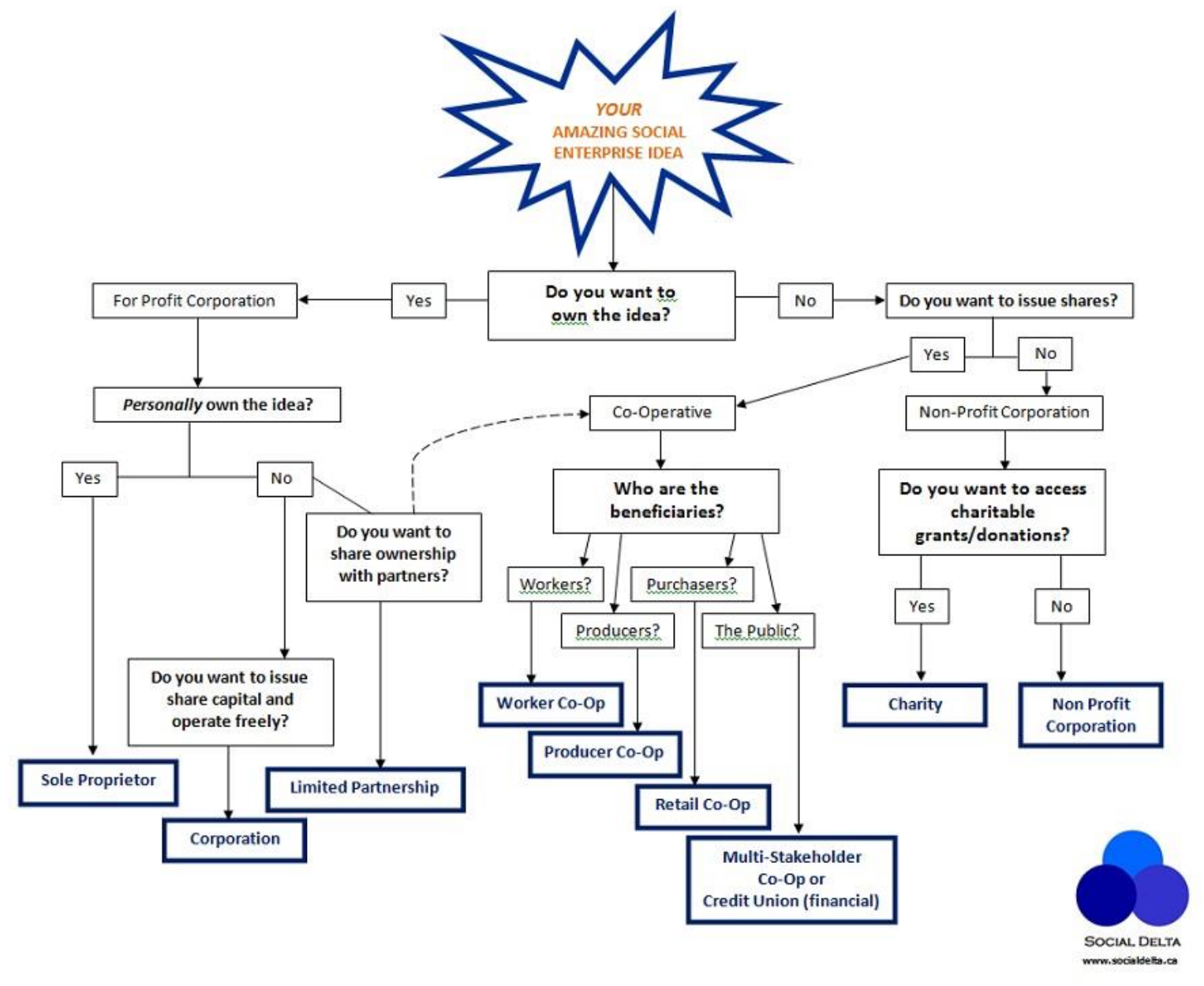

Figure 2. Your amazing social enterprise idea [decision tree] (Social Delta, 2015). Reprinted with permission.

\section{Marketing Budget}

Many studies have shown that marketing dollars must be invested in order to achieve returns. Social Enterprise Toronto interviewed 32 social enterprises and found that 50 per cent of social enterprises had no marketing budget, and of those that did, more than half spent less than five per cent of total revenues on marketing (Social Enterprise Toronto, 2014). Entrepreneur magazine suggests that new companies (one to five years old) spend 12 to 20 per cent of gross or projected revenue on marketing, whereas enterprises in business for more than five years spend between six and 12 per cent (Mintz, 2015). This suggests that a significant opportunity for growth would be to increase the marketing budget, although that may feel challenging, and possibly even a frivolous use of money to social enterprises struggling to attract financing. Still, research suggests that marketing investment should be a priority. There are also free marketing channels available to social enterprises, especially with the popularity of free social media channels such as Facebook, YouTube, Twitter, and LinkedIn. Further, the likes of Akcelos, a 
new responsible purchasing platform, makes it easier for consumers to purchase from companies with certified social values (Akcelos, 2018).

\section{Access to Financing and Other Barriers to Growth}

The ability to grow or scale up one's social enterprise is just as important as it is for other business types (or perhaps even more so given the motivation to generate social returns). However, due to the relatively early stage of many social enterprises, executive directors are more focused on short-term performance than on long-term sustainability (Menon et al, 2015). Social enterprises can encounter several common barriers; firstly, the sector's inexperience with financial metrics and measurement can make it difficult for social enterprises to even measure let alone communicate the value they have to offer, which in turn makes it difficult to attract the financial support needed to scale up; secondly, that it can be difficult for newer social enterprises to attract funding on account of a short performance history (Menon et al, 2015). Many social enterprises get started with grant money and irregular donor funding, which is also challenging as many grants are tied to requirements such as funding 'innovation' as opposed to funding operations. Without operations support and capacity, it is near impossible for a social enterprise to grow (Crawford, Urban, and Yip, 2017). Thirdly, as previously mentioned, most banks do not provide large three- to five-year loans and social enterprises typically do not meet the profitability requirements to qualify for commercial funds (Menon et al, 2015).

\section{Financing Sources}

Where do social enterprises turn for financing? In their 2016 Canadian National Social Enterprise Sector Survey (which excluded Québec), Elson et al (2016) found the main sources of grants for social enterprises were provincial (49 per cent), federal (30 per cent) and municipal governments ( 29 per cent). Other grant sources included private individuals (42 per cent), foundations ( 25 per cent) and corporations ( 27 per cent). Of note, 23 per cent of social enterprises in Canada received no grants. As for loans, only eight per cent of social enterprises received loans from banks, seven per cent from credit unions, and two per cent from provincial government and private individuals. Seventy-four per cent of social enterprises received no loans. This highlights how dependent social enterprises are on all levels of government for resources. It also demonstrates the little-known yet important role that foundations play in supporting social enterprise. Two foundations known for championing social enterprise are McConnell Foundation and Lawson Foundation. The Toronto-based MaRS innovation hub is another key supporter. MaRS offers a comprehensive funding research portal for social enterprise needs, available at www.marsdd.com/funding/search/.

That said, some social enterprises do earn enough profits to attract investors. In these instances, investment capital is typically provided in five main forms: Equity (acts as 'patient capital' for a 
longer period, and comes with an ownership stake in the enterprise); Debt (typically requires repayment to start soon afterwards); Equity Equivalent (functions as patient capital but is usually structured as debt); Grants (non-repayable); and Internally Generated Funds (through positive cash flow or 'sweat equity') (Manitoba Division of the Canadian CED Network, 2009).

Another emerging model is the blended donor-investor model for attracting capital - also known as social impact investment (Daggers \& Nicholls, 2016). Funders interested in social returns are approached for capital, with private sector investors covering the remainder. Foundations are often most interested in social returns and do not always require repayment, allowing the social enterprise to advance its social work and then repay just the private sector investor, a scenario in which everybody 'wins'. Impact investing has begun to develop in several countries, particularly in the United States and United Kingdom, but also in Australia, Germany, India, China, France, Belgium, Canada and elsewhere (Daggers et al, 2016). Other financial mechanisms being used to support social enterprise and reduce investment risk are loan guarantees, fund pooling, and social impact bonds (Bugg-Levine, Kogut, and Kulatilaka, 2012). Regardless of the investment source, all investors require some evidence of potential impact, which makes performance measurement critically important for the future success of social enterprises.

\section{Social Impact Measurement}

Of the many barriers to success that social enterprises face, performance measurement remains a key obstacle given the absence of a rigorous common approach to measuring and reporting on social impact. The Ontario-based Social Enterprise Impact Measurement Task Force (2017), which studied the sector's capabilities and made recommendations for the future, observed that measurement must be easy to implement, and achieve its goals with proportionate costs and effort. The taskforce flagged that a complex reporting regime raises the cost of doing business, and restricts opportunities for growth. The taskforce recommended the development of a common framework, process, and set of social and environmental indictors as an important assist to social enterprises given that many lack performance measurement knowledge and capabilities (Social Enterprise Impact Measurement Task Force, 2017). Further, installing a common approach would allow data to be captured and aggregated to form a picture of the contribution of social enterprise activity in Ontario. This common framework is now being piloted by Carleton Centre for Community Innovation in partnership with other key organizations, including Canadian Community Economic Development Network, Pillar Non-profit Network, and Center for Social Innovation among the core partners, and the UN SDG Impact Fund, Purpose Capital, Standards Council of Canada, and Common Good Solutions as some of the network partners (Hebb, 2019). This social enterprise measurement remains part of Ontario's Social Enterprise Strategy 2016-2021, despite the change of provincial government. In June 2018, the Progressive Conservative Government was elected to power and began making immediate changes to business priorities for the province (along with program cancellations and overhauls of the 
education, environment, health and Indigenous mandates too). As one example, the Ontario government has cancelled the basic income pilot program (more information about that later in this paper). This illustrates how the political will of the government of the day can have significant impact on social enterprises' opportunities, funding, profile, and viability.

\section{Policies to Support Social Enterprise}

\section{Develop social enterprise strategies within provincial and territorial governments}

The Liberal Government of Ontario had released a Social Enterprise Strategy for 2016 to 2021, which included establishing a Centre of Excellence in Social Enterprise and Social Finance, offering a Social Enterprise Demonstration Fund, designing an investment fund to encourage more private investment capital in social enterprise, and increasing its procurement from social enterprises (Government of Ontario, 2016). According to the government's web page, this Fund does not appear to have been altered by the new government (Government of Ontario, 2018). Similarly, the Government of British Columbia is developing social impact purchasing guidelines, and launched a social innovation online community (Government of British Columbia, n.d.). In April 2017, the Government of Nova Scotia released a framework for advancing social enterprise. The framework was accompanied by an initial $\$ 200,000$ investment to support the development of an online portal where entrepreneurs can access training and resources (Common Good Solutions, 2017). These are just a few examples of provincial policies underway in Canada to support social enterprises.

\section{Create New Legal Entities That Allow Social Enterprises to Access More Funding and Contracts}

Recognizing the value of social enterprises, several provinces have introduced legislation to make it easier for social enterprises to thrive. In November 2012, Nova Scotia introduced legislation under the Community Interest Companies Act to allow vetted businesses in Nova Scotia to be designated as Community Interest Companies (CIC). This recognizes the social purpose, while permitting the social enterprise to engage in activities with a profit motive and to issue shares. However, what makes a CIC different from a typical business corporation is that CICs are restricted on the annual amount of dividends or interest they may return to investors (Smith, 2016). The Nova Scotia government also introduced a Social Enterprise Loan Guarantee for local credit unions loaning to "not-for-profit, non-profit, cooperatives and social purpose businesses, which are for profit but designed to fulfill a social mission". The guarantee covers up to 90 per cent of loans up to $\$ 150,000$ (Futurpreneur Canada, n.d.). Shortly after this, in 2013 the Government of British Columbia introduced a new category of corporations called the 'Community Contribution Company' (also known as a CCC), which combines elements of a for-profit model with those of a non-profit. This allows entrepreneurs to pursue social goals through their businesses while still generating a profit and providing investment opportunities to 
like-minded investors (Ministry of Finance, Government of British Columbia, n.d.). In addition, these legal designations indicate that participating organizations have been vetted. This might make it easier for those social enterprises to attract financing, and may also permit more tax breaks.

\section{Include Social Enterprises in Government Procurement}

The Canadian Community Economic Development Network (CCEDNET) has made recommendations over the years that government departments should adopt social procurement policies that support blended returns, which account for social and environmental outcomes in addition to financial returns. CCEDNET has praised the United Kingdom government for its Social Values Act, the first step in encouraging the government to purchase from social enterprises (Toye, 2015). CCEDNET has also recommended that governments split larger contracts into smaller components so that social enterprises can qualify to bid. The advantage to government would be reducing the risk of relying on just one organization to deliver the product or service. Other recommendations include: assign points for anticipated social value, give bonus points to larger companies that have indicated they will sub-contract to social enterprises, reduce or remove the requirement for bid bonds and other insurance, and implement some wage equity guidelines for suppliers so that their workers must earn a living wage (Manitoba Division of the Canadian CED Network, 2009). As mentioned, the Government of Ontario launched a Social Enterprise Demonstration Fund to provide several million dollars in funding to not-for-profit organizations with expertise in supporting social enterprises through capacity building, grants or loans in order to strengthen the social enterprise eco-system (Government of Ontario, 2017b). Additionally, in November 2017, Ontario's Ministry of Economic Development and Growth launched a Call for Proposals to find a program administrator to oversee a Social Enterprise Procurement and Investment Readiness Fund, which will support social enterprises in assessing procurement and investment readiness, and accessing capacity building supports to become more competitive. At least $\$ 4.5$ million in grants will be allocated to support this work (Ontario Ministry of Economic Development and Growth, 2017b; 2018).

\section{Tax Breaks for Social Enterprise}

The implementation of the above suggestions would allow many more social enterprises to take advantage of the purchasing power of government. But governments can help in more ways beyond being a buyer. For example, governments could offer partial tax subsidies to investors financing social enterprises (Menon et al, 2015). CCEDNET has praised the New Brunswick government for extending the small business tax credit to 'blended value' businesses too, and the Nova Scotia and Manitoba governments for extending the small business tax credit to also include co-operatives (Toye, 2015). 


\section{Offer a Basic Income to Social Entrepreneurs}

In May 2017, the Mowat Centre published a report looking at the impacts of introducing a basic income to assist social entrepreneurs. They presented that a basic income would de-risk experimentation while providing critical 'pre-seed' funding for early-stage social entrepreneurs, which could be used to pay operating costs (rent, salaries, IT upgrades) - all essential areas that government grants typically do not cover. In addition, a basic income would address the lag time between applying for and receiving grants (for those enterprises with charitable status that qualify for grants), while providing a source of income to social enterprises without charitable status that are not eligible for grants (Crawford Urban et al, 2017).

Under the Liberal Party, the Government of Ontario had launched a basic income pilot to test the impact of a basic income in communities including Hamilton, Thunder Bay, and Lindsay. Up to 4,000 participants between the ages of 18 and 64 were to be randomly selected to receive up to $\$ 16,989$ per year for a single person, and up to $\$ 24,027$ for couples (less 50 per cent of any earned income). People with disabilities would receive an additional \$6,000 (Government of Ontario, 2017a). However, shortly after the new Progressive-Conservative Government of Ontario was elected in mid-2018, it announced that the basic income pilot would end March 31, 2019 (a year early) on account of the cost and its perception that the focus was misdirected (Rushowy, 2018). This has caused disappointment and resistance among recipients, as well as advocates for basic income. Some are calling on the federal government to take over the basic income trial, but any uptake remains to be seen (Rushowy, 2018).

\section{Conclusion}

Small businesses and social enterprises contribute significantly to the economy by generating revenue, increasing GDP, creating jobs, and - in the case of some social enterprises - employing people who may otherwise struggle to get hired. Despite this great potential for positive impact, both business types struggle to access financing, support, and opportunities of scale that would increase the chance of sustainability. However, evidence suggests that much can be done to improve the likelihood of success for both. It is critical that all entrepreneurs validate market need for the product or service in mind, select the right business model, assemble the team and resources needed to ensure quality output, secure financing and cashflow, and invest in marketing (even moreso at the outset) to attract customers and gain market share. That said, while all these components are critical for individual business success, improving the external support systems will make the most significant difference in helping more small businesses and social enterprises to succeed over time and stay in business beyond the notorious five-year mark. As discussed throughout this paper, the business characteristics and available financing mechanisms differ between small business and social enterprise, but the key factors that both require for success are very similar. Those factors can be summarized as financial security, 
access to market opportunities, and building capacity through an improved business ecosystem, as recapped below.

For both types of organizations, the choice of business model greatly affects the financing and credit sources available. As such, this decision must be carefully considered at the outset. For small business, access to investors and lending institutions is critically important, as government grants often carry many conditions, restricting eligibility and also the quick release of funds. Municipal governments and local chambers of commerce could assist by tracking capital flows, making more efforts to match businesses with investors, and enhancing the local lending capacity. The business counsel, grants and loans offered by Community Futures Development Corporations have shown to have significant impact on enterprise success and resilience too. For social enterprise, the greatest need is access to unrestricted government and foundation grants that could be used to fund key business operations rather than another new 'innovation'. While at present only registered charities are eligible for philanthropic grants, excluding non-profit social enterprises that do not possess charitable status, the proposed regulatory changes would allow foundations to offer alternate financing mechanisms to noncharitable organizations in the business of doing good. Further, the development of a social impact measurement framework for the sector will assist leaders of social enterprises to demonstrate the impact of their work, which can then be leveraged to attract more financing.

While both business types require access to opportunities, the nature of social enterprises (investing any profits into the community rather than back into the business; in other cases employing disadvantaged people who may reduce productivity because they require more supervision) often makes these organizations less competitive than a typical small business. Governments at all levels can help social enterprises through procurement policies that make contracts more accessible to these organizations. As for small businesses, the federal government is starting to introduce more opportunities to support their entry into the global export market, especially given the promising returns seen by some. Much can and should be done to help small businesses and social enterprises to succeed and sustain. Positive repercussions will extend well beyond the business sector into the wider community and economy.

\section{Author Biography}

Tina Barton was born and raised in New Zealand, where she completed her undergraduate degree. After receiving a Bachelor of Arts in Political Science and a Graduate Diploma of Journalism, she travelled the world extensively, exploring urban and rural life across the continents before settling in Ottawa, Canada. Tina has held partnership, marketing and communications positions in the private, non-profit, and media sectors. She has volunteered to help immigrant newcomers find professional opportunities, with urbanists to make architecture more accessible, and with the international business communications community. Tina is 
interested in the correlation between urban planning and economic opportunity, sustainable market economies, and environmental and social justice. Tina is completing a Master's in Economic Development and Innovation with the University of Waterloo.

\section{References}

Abrams, R. (2017, May 31). Millennials and small business go well together, study says. USA Today. Retrieved from https://www.usatoday.com/story/money/columnist/abrams/2017/05/31/millennials-and-smallbusiness-go-well-together-study-says/101469364/

Akcelos, (2018). Your new online address for social and sustainable purchases. Retrieved from https://www.akcelos.com/en

Almubartaki, H., Al-Karaghouli, W. \& Busler, M. (2010). The creation of business incubators in supporting economic developments. Retrieved from https://www.researchgate.net/profile/Michael_Busler/publication/228457195_The_Creation_of_ Business_Incubators_in_Supporting_Economic_Developments/links/00b4953ca7970aa7c30000 00/The-Creation-of-Business-Incubators-in-Supporting-Economic-Developments.pdf

Bonnstetter, B. (2013, April 1). The skills most entrepreneurs lack. Harvard Business Review. Retrieved from https://hbr.org/2013/04/the-much-needed-skills-most-en Bowdler, J., \& Zeull, K. (2016, November 8). What cities should be doing for small business. Governing. Retrieved from http://www.governing.com/gov-institute/voices/col-cities-focuseconomic-development-job-strategies-small-business.html

Bugg-Levine, A., Kogut, B., \& Kulatilaka, N. (2012, January). A new approach to funding social enterprises. Harvard Business Review. Retrieved from https://hbr.org/2012/01/a-new-approachto-funding-social-enterprises

Business Development Bank of Canada (n.d.). Global business: Why you need to look beyond Canada and expand internationally. Retrieved from https://www.bdc.ca/en/articlestools/marketing-sales-export/exportation/pages/expanding-internationally.aspx ?type=A\&order=1 Butler, D. (2016, October 28). Innovation centre ready to nurture poverty-busting social enterprises. Ottawa Citizen. Retrieved from http://ottawacitizen.com/news/localnews/innovation-centre-ready-to-nurture-poverty-busting-social-enterprises

Calabrese, D. (2016, February 16). Ottawa studying how to help Canadian tech startups become billion-dollar firms. National Post. Retrieved from http://business.financialpost.com/entrepreneur/fp-startups/ottawa-studying-how-to-help- 
canadian-tech-startups-become-billion-dollar-firms/wcm/8077c9f4-2438-4ae2-a1de$\underline{5 \mathrm{aaeb} 04 \mathrm{c} 0 \mathrm{fad}}$

Canada Business Network, (n.d.). Succession planning. Retrieved from https://canadabusiness.ca/business-planning/succession-planning/

Canadian Federation of Independent Business, (n.d.) A practical list for new entrepreneurs: Steps to take when opening a business. Retrieved from https://www.cfib-fcei.ca/en/toolsresources/practical-list-new-entrepreneurs-steps-take-when-opening-business

Canadian Federation of Independent Business (2016). Canada's small business owners are four times more likely to be low income than rich. Retrieved from https://www.cfibfcei.ca/en/media/canadas-small-business-owners-are-four-times-more-likely-be-low-incomerich-sk

Canadian Federation of Independent Business, (2017a). Federal tax reform: What we're doing to get the government to halt its unfair plan. Retrieved from https://www.cfib-

fcei.ca/en/advocacy/federal-tax-reform-what-were-doing-get-government-halt-its-unfair-plan

Canadian Federation of Independent Business (2017b). Small business tax rate going down: More money for your business. Retrieved from

https://www.cfib-fcei.ca/en/advocacy/small-business-tax-rate

Carter, T. S., \& Man, T. L. M., (2008). Canadian registered charities: Business activities and social enterprise - thinking outside the box. Retrieved from http://www.carters.ca/pub/article/charity/2008/tsc1024.pdf

Common Good Solutions (2017, April 17). NS Government releases first ever social enterprise framework. [News release]. Retrieved from http://commongoodsolutions.ca/blog/category/nsgovernment-releases-first-ever-social-enterprise-framework

Crawford Urban, M., \& Yip, C. (2017). Basic impact: Examining the potential impact of a basic income on social entrepreneurs. Retrieved from https://mowatcentre.ca/wpcontent/uploads/publications/148_basic_impact.pdf

Daggers, J., \& Nicholls, A. (2016). The landscape of social impact investment research: Trends and opportunities. Retrieved from https://www.sbs.ox.ac.uk/sites/default/files/researchprojects/CRESSI/docs/the-landscape-of-social-impact-investment-research.pdf 
Department of Finance, Government of Canada (2017). Backgrounder: Support for risk taking and entrepreneurship. Retrieved from https://www.canada.ca/en/departmentfinance/news/2017/10/backgrounder_supportforrisktakingandentrepreneurship.html

Elson, P., Hall, P., \& Wamucii, P. (2016). Canadian National Social Enterprise Sector Survey Report 2016. Retrieved from https://ccednet-rcdec.ca/sites/ccednet-rcdec.ca/files/final-nationalreport-may-16-2016.pdf

Employment and Social Development Canada (2018). Recommendations of the Social Innovation and Social Finance Strategy Co-Creation Steering Group. Retrieved from https://www.canada.ca/en/employment-social-development/programs/social-innovation-socialfinance/reports/recommendations-what-we-heard.html?

Enterprising Non-Profits (2010). The Canadian Social Enterprise Guide (2nd ed.). Retrieved from https://www.vancity.com/AboutVancity/VisionAndValues/ValuesBasedBanking/FinancialLitera cyAndBasicBanking/The-Canadian-Social-Enterprise-Guide.pdf

Ference Weicker \& Company Ltd. (2014). Evaluation of the Community Futures Program: Report prepared for the Federal Economic Development Agency for Southern Ontario. Retrieved from

http://www.feddevontario.gc.ca/eic/site/723.nsf/eng/h_02064.html?OpenDocument

Futurpreneur Canada (n.d.). Choosing a legal structure for social purpose business. Retrieved from http://www.futurpreneur.ca/en/resources/social-purpose-business/articles/choosing-a-legalstructure-for-social-purpose-business/

Galang, J. (2016). Canadian Government announces \$50 Million program to help SMBS with global export. Retrieved from https://betakit.com/canadian-government-announces-50-millionprogram-to-help-smbs-with-global-export/

Global Affairs Canada, (2016, November 23). CanExport hits impressive milestone: 500 Canadian small and medium-sized enterprises funded to reach new international markets. [Press release]. Retrieved from: www.canada.ca/en/global-affairs/news/2016/11/canexport-hitsimpressive-milestone-500-canadian-small-medium-sized-enterprises-funded-reach-newinternational-markets.html

Goldstein, M. (n.d.) What startups need to know before applying to an incubator. [Blog post]. Retrieved from https://www.coxblue.com/what-startups-need-to-know-before-applying-to-anincubator/ 
Government of British Columbia (n.d.). Social innovation. Retrieved from http://www2.gov.bc.ca/gov/content/employment-business/business/social-innovation

Government of Ontario (2016). Ontario’s Social Enterprise Strategy 2016-2021.

Retrieved from https://www.ontario.ca/page/ontarios-social-enterprise-strategy-2016-2021

Government of Ontario (2017a). Ontario's basic income pilot: Studying the impact of a basic income. Retrieved from https://files.ontario.ca/170508_bi_brochure_eng_pg_by_pg_proof.pdf

Government of Ontario (2017b; 2018). Social Enterprise Demonstration Fund. Retrieved from https://www.ontario.ca/page/social-enterprise-demonstration-fund

Grant, T. (2015, May 29). Canadian entrepreneurship on the rise but many firms struggle to grow. Globe and Mail. Retrieved from https://www.theglobeandmail.com/report-onbusiness/economy/canadian-innovation-at-a-peak-but-struggling-to-move-up-businessladder/article24680299/

Greene, P. (2014, April 3). What do small businesses really need to grow? Forbes. Retrieved from https://www.forbes.com/sites/babson/2014/04/03/what-do-small-businesses-really-need-togrow/\#5037f479efa3

Hallen, B. L., Bingham, C. B., \& Cohen, S. L. (2014). Do accelerators accelerate? A study of venture accelerators as a path to success. Academy of Management Proceedings, (1). doi:10.5465/AMBPP.2014.185. Retrieved from https://papers.ssrn.com/sol3/papers.cfm?abstract_id=2719810

Hebb, T. (2019, January 7). Re: Question: Social Enterprise Impact Measurement Task Force. Carleton Centre for Community Innovation [Email correspondence].

Henry, P. (2017, February 18). Why some startups succeed (and why most fail). Entrepreneur. Retrieved from https://www.entrepreneur.com/article/288769.

Hurley, K. (2016). From social enterprise to social franchise: An introductory guide to achieving scale through replication. Retrieved from https://ccednet-rcdec.ca/en/toolbox/social-enterprisesocial-franchise-introductory-guide

Industry Canada (2012). Key small business statistics. Retrieved from https://www.ic.gc.ca/eic/site/061.nsf/vwapj/KSBS-PSRPE_JulyJuillet2012_eng.pdf/\$FILE/KSBS-PSRPE_July-Juillet2012_eng.pdf 
Innovation, Science and Economic Development Canada (2016). Key small business statistics. Retrieved from https://www.ic.gc.ca/eic/site/061.nsf/vwapj/KSBS-PSRPE_JuneJuin_2016_eng.pdf/\$FILE/KSBS-PSRPE_June-Juin_2016_eng.pdf

Invest Ottawa (n.d.). Incite Incubator. Retrieved from https://www.investottawa.ca/inciteincubator/

Kalender, C., ( 2017, October 11). 150 Accelerators and incubators in Canada. [Blog post] Retrieved from https://medium.com/mentornity-blog/150-accelerators-and-incubators-in-canada$\underline{6111 \mathrm{e} 89 \mathrm{e} 2 \mathrm{fd} 8}$

Launch Academy (n.d.). Welcome to Vancouver's leading startup hub [Web site]. Retrieved from https://www.launchacademy.ca/

Manitoba Division of the Canadian CED Network (2009). Creating a robust social enterprise sector in Winnipeg. Retrieved from https://ccednet-rcdec.ca/files/ccednet/SE_Report_feb_09.pdf

MaRS (2009). Legal Considerations - Registered charities. Retrieved from https://www.marsdd.com/mars-library/legal-considerations-registered-charities/

McKinnon, S., (n.d.). What does it mean to start a social enterprise. Carleton University; Carleton Centre for Community Innovation. Retrieved from https://carleton.ca/3ci/wp-content/uploads/3ci-Social-Enterprise-Primer.pdf

Menon, N., Swarup, R., Nicholson J., \& Khan, S., (2015). Scaling up: Catalyzing the social enterprise. Retrieved from https://www.atkearney.com/documents/10192/5487100/Scaling+Up\%E2\%80\%B9Catalyzing+th e+Social+Enterprise.pdf/1f1a024a-a7a5-4763-8739-50887139df47

MentorWorks Ltd (n.d.)a. Canadian government funding for small businesses. Retrieved from https://www.mentorworks.ca/what-we-offer/government-funding/

MentorWorks (n.d.)b. FAQs: Canadian grants \& loans for businesses. Retrieved from https://www.mentorworks.ca/who-we-are/faqs/

Miller, M., Seigel, B., \& McComas, M. (2017). Financing Baltimore's growth: Measuring small companies' access to capital. Retrieved from http://21cc.jhu.edu/wpcontent/uploads/2017/09/21cc-financing-baltimores-growth-sept-2017.pdf 
Ministry of Finance, Government of British Columbia (n.d.). Community contribution companies. Retrieved from http://www.fin.gov.bc.ca/prs/ccc/

Mintz, L. (2015, March 11). How to determine the perfect marketing budget for your company. Entrepreneur. Retrieved from https://www.entrepreneur.com/article/243790

Northern Alberta Business Incubator (2014). About NABI [Web site]. Retrieved from http://www.nabi.ca/AboutUs.aspx

O’Connor, P. (2014). The new regulatory regime for social enterprises in Canada: Potential impacts on nonprofit growth and sustainability. Retrieved from http://www.ryerson.ca/content/dam/cvss/AODAforms/datedPapers/WP\%202014.1.OConnorSocial\%20EnterpriseRegRegime.FINAL.Working\%20Paper.\%200ct.21.2014.pdf

Ogutu, V. O., \& Kihonge, E., (2016). Impact of business incubators on economic growth and entrepreneurship development. International Journal of Science and Research, 5 (5). Retrieved from https://www.ijsr.net/archive/v5i5/NOV163196.pdf

Ontario Investment Office (2017, May 12). Canada is one of the best places in the world for social entrepreneurs. Retrieved from https://www.investinontario.com/spotlights/canada-one-best-places-world-social-entrepreneurs

Ontario Ministry of Economic Development and Growth (2017b, November 10; 2018, June 26). Social Enterprise Procurement and Investment Readiness Fund [Call for Proposals: PDF].

Pelot, L. (1998). A profile of small business across Canada. Insights On, 2 (3), 1-12. Retrieved from http://publications.gc.ca/Collection/Statcan/61F0019X/io98010e.pdf

Ratté, S. (2016). The Scale Up Challenge: How are Canadian companies performing? Retrieved from https://www.bdc.ca/en/about/sme_research/pages/the-scale-up-challenge.aspx

Ries, L. (2016). An entrepreneurial approach to job creation in rural Canada. Retrieved from https://communityfuturescanada.ca/wp-content/uploads/1467380865195_Lori_Ries.pdf

Rushowy, K. (2018, August 31). Basic income pilot project to end March 31. Toronto Star. Retrieved from https://www.thestar.com/news/queenspark/2018/08/31/basic-income-pilotproject-to-wind-up-march-31.html

Seens, D. (2015). SME Profile: Canadian Exporters. Retrieved from https://www.ic.gc.ca/eic/site/061.nsf/eng/h 02925.html 
Social Delta, (2015). Your amazing social enterprise idea [decision tree].

Retrieved December 13, 2017. [Email correspondence].

Social Enterprise Impact Measurement Task Force (2017). Amplifying the impact of Ontario's social enterprise community: An action plan towards a common approach to impact measurement. Retrieved from https://carleton.ca/3ci/wp-content/uploads/IM-TF-Action-PlanReport-ENGLISH.pdf

Social Enterprise Toronto (2014). Thriving or surviving: Social enterprises in the GTA. Retrieved from https://ccednet-rcdec.ca/en/toolbox/thriving-surviving-social-enterprises-gta

Smith, N. (2016, July 6). An in-depth look at Nova Scotia's new Community Interest Companies. Retrieved from http://www.millerthomson.com/en/publications/communiques-andupdates/social-impact-newsletter-formerly-the/july-6-2016/an-in-depth-look-at-nova-scotiasnew/

Statistics Canada (Consulting Analyst), (2018, March 15). Re: Request: Average revenue of small businesses in Canada - report available? [Email correspondence].

Tal, B., \& Mendes, R. (2015). Times are a changin' for SMEs. Retrieved from http://research.cibcwm.com/economic_public/download/if_2015-1022.pdf

Tasic, I., Montoro-Sánchez, A., \& Cano, M.D., (n.d.). Startup accelerators: An overview of the current state of the acceleration phenomenon. Retrieved from http://www.aeca1.org/pub/on_line/comunicaciones_xviiicongresoaeca/cd/130c.pdf

Toye, M. (2015). Policy proposals for Canada's social economy. Retrieved from https://ccednet-rcdec.ca/sites/ccednetrcdec.ca/files/social_economy_policy_proposals_20150427.pdf

Venn, D. (2017, November 20). Social enterprise: Charitable campus creates new opportunities and synergies for Calgary nonprofits. Retrieved from http://communityfoundations.ca/socialenterprise-charitable-campus-creates-new-opportunities-synergies-calgary-nonprofits/

Weaver, R. (2014, November 5). The six biggest barriers facing small businesses in Canada. Globe and Mail. Retrieved from https://www.theglobeandmail.com/report-on-business/smallbusiness/sb-growth/day-to-day/six-big-challenges-facing-small-businesses-incanada/article21437327/ 
Wilber, P.L., \& Dixon, L. (n.d.). The impact of business incubators on small business survivability. Retrieved from

http://citeseerx.ist.psu.edu/viewdoc/download?doi=10.1.1.598.6767\&rep=rep1\&type=pdf 